\title{
Improvements over time in short-term mortality following myocardial infarction in HIV-positive individuals
}

Hatleberg, Camilla Ingrid ; Ryom, Lene ; El-Sadr, Wafaa ; Smith, Colette ; Weber, Rainer ; Reiss, Peter ; Fontas, Eric ; Dabis, Francois ; Law, Matthew ; Monforte, Antonella d'Arminio ; De Wit, Stephane ; Mocroft, Amanda ; Phillips, Andrew ; Lundgren, Jens D ; Sabin, Caroline

\begin{abstract}
OBJECTIVE Few studies have described mortality and clinical outcomes after myocardial infarction (MI) in the HIV-positive population. This study evaluated changes in short-term mortality after MI in HIV-positive individuals in the D:A:D Study, and investigated possible reasons for any changes seen. DESIGN Prospective cohort study. METHODS Demographic, cardiovascular disease (CVD)/HIVrelated characteristics and CVD-related interventions (invasive cardiovascular procedures and drug interventions) were summarized at the time of and following an MI. Associations between calendar year and mortality in the first month after MI were identified using logistic regression with adjustment for confounders, including interventions received in the first month after MI. RESULTS One thousand and eight HIV-positive individuals experiencing an MI over the period 1999-2014 were included. The absolute number of MIs decreased from 214 (1999-2002) to 154 (2011-2014). Whilst the CVD risk profile remained high over time, the HIV status improved. The use of CVD-related interventions after MI appeared to increase over time. The proportion of individuals who died in the first month after MI dropped from $26.6 \%$ in $1999-2002$ to $8.4 \%$ in 2011-2014. Later calendar year was associated with decreased short-term mortality; this effect was attenuated after adjusting for CVD-related interventions received in the first month after MI [odds ratio changed from 0.88 (95\% confidence interval $0.83,0.93)$ to $0.97(0.91,1.02)$ ]. CONCLUSION Improvements in short-term survival after MI appear to be largely driven by improved medical management of CVD risk in HIV-positive individuals after MI. Efforts are still needed to treat CVD risk factors and increase access to CVD-related interventions.
\end{abstract}

DOI: https://doi.org/10.1097/QAD.0000000000001076

Posted at the Zurich Open Repository and Archive, University of Zurich

ZORA URL: https://doi.org/10.5167/uzh-125199

Journal Article

Published Version

Originally published at:

Hatleberg, Camilla Ingrid; Ryom, Lene; El-Sadr, Wafaa; Smith, Colette; Weber, Rainer; Reiss, Peter; Fontas, Eric; Dabis, Francois; Law, Matthew; Monforte, Antonella d'Arminio; De Wit, Stephane; Mocroft, Amanda; Phillips, Andrew; Lundgren, Jens D; Sabin, Caroline (2016). Improvements over time in short-term mortality following myocardial infarction in HIV-positive individuals. AIDS, 30(10):15831596.

DOI: https://doi.org/10.1097/QAD.0000000000001076 


\title{
Improvements over time in short-term mortality following myocardial infarction in HIV-positive individuals
}

\author{
Camilla Ingrid Hatleberg ${ }^{\mathrm{a}}$, Lene Ryom ${ }^{\mathrm{a}}$, Wafaa El-Sadr ${ }^{\mathrm{b}}$, \\ Colette Smith', Rainer Weber ${ }^{\mathrm{d}}$, Peter Reiss ${ }^{\mathrm{e}}$, Eric Fontas ${ }^{\mathrm{f}}$, \\ Francois Dabis ${ }^{g}$, Matthew Law ${ }^{\mathrm{h}}$, Antonella d'Arminio Monforte', \\ Stephane De Wit ${ }^{j}$, Amanda Mocroft ${ }^{c}$, Andrew Phillips ${ }^{c}$, \\ Jens D. Lundgren ${ }^{a}$, Caroline Sabin', for the D:A:D Study Group
}

Objective: Few studies have described mortality and clinical outcomes after myocardial infarction (MI) in the HIV-positive population. This study evaluated changes in short-term mortality after MI in HIV-positive individuals in the D:A:D Study, and investigated possible reasons for any changes seen.

Design: Prospective cohort study.

Methods: Demographic, cardiovascular disease (CVD)/HIV-related characteristics and CVD-related interventions (invasive cardiovascular procedures and drug interventions) were summarized at the time of and following an MI. Associations between calendar year and mortality in the first month after MI were identified using logistic regression with adjustment for confounders, including interventions received in the first month after MI.

Results: One thousand and eight HIV-positive individuals experiencing an MI over the period 1999-2014 were included. The absolute number of Mls decreased from 214 (1999-2002) to 154 (2011-2014). Whilst the CVD risk profile remained high over time, the HIV status improved. The use of CVD-related interventions after MI appeared to increase over time. The proportion of individuals who died in the first month after MI dropped from $26.6 \%$ in $1999-2002$ to $8.4 \%$ in $2011-2014$. Later calendar year was associated with decreased short-term mortality; this effect was attenuated after adjusting for CVD-related interventions received in the first month after $\mathrm{MI}$ [odds ratio changed from 0.88 (95\% confidence interval $0.83,0.93)$ to $0.97(0.91,1.02)]$.

Conclusion: Improvements in short-term survival after MI appear to be largely driven by improved medical management of CVD risk in HIV-positive individuals after MI. Efforts are still needed to treat CVD risk factors and increase access to CVD-related interventions.

Copyright (c) 2016 Wolters Kluwer Health, Inc. All rights reserved.

AIDS 2016, 30:1583-1596

Keywords: cardiovascular disease, cardiovascular interventions, HIV infection, mortality, myocardial infarction

\footnotetext{
${ }^{a}$ CHIP, Department of Infectious Diseases, Section 2100, Rigshospitalet, University of Copenhagen, Copenhagen, Denmark, b ICAP-Columbia University and Harlem Hospital, New York, USA, ' Research Department of Infection and Population Health, UCL, London, UK, d Division of Infectious Diseases and Hospital Epidemiology, University Hospital Zurich, University of Zurich, Zurich, Switzerland, eAcademic Medical Center, Department of Global Health and Division of Infectious Diseases, University of Amsterdam, and HIV Monitoring Foundation, Amsterdam, The Netherlands, fDepartment of Public Health, Nice University Hospital, Nice, ' Université de Bordeaux, ISPED, Centre INSERM U897-Epidémiologie-Biostatistique, Bordeaux, France, hThe Kirby Institute, UNSW Australia, Sydney, Australia, 'Dipartimento di Scienze della Salute, Clinica di Malattie Infettive e Tropicali, Azienda Ospedaliera-Polo Universitario San Paolo, Milan, Italy, and 'Division of Infectious Diseases, Saint Pierre University Hospital, Université Libre de Bruxelles, Brussels, Belgium.
}

Correspondence to Camilla Ingrid Hatleberg, MD, CHIP, Department of Infectious Diseases, Section 2100, Rigshospitalet, University of Copenhagen, Blegdamsvej 9, DK-2100 Copenhagen, Denmark.

Tel: + 45354557 70; fax: +45 354557 57; e-mail: Camilla.hatleberg@regionh.dk Received: 6 January 2016; revised: 17 February 2016; accepted: 18 February 2016. 


\section{Introduction}

The mortality rate after a first myocardial infarction (MI) has declined in individuals of all ages in the general population over the past 25 years $[1,2]$. This improvement is mainly attributable to better management of cardiovascular disease (CVD) risk factors and the increased use of recommended medical therapies and invasive cardiovascular procedures (ICPs) $[1,2]$. It is well documented that HIV-positive persons have a higher risk of CVD; multiple factors, not all of which are fully explained, may contribute to development of atherosclerosis in this population. The prevalence of many traditional CVD risk factors (e.g. smoking, dyslipidemia) is higher in HIVpositive persons than in the general population $[3,4]$. Although some studies have reported an improvement over the years [5], earlier findings from the D:A:D Study demonstrated that the CVD risk profile of individuals living with human immunodeficiency virus (HIV) in the cohort generally worsened from 1999 to 2006 [6]. In addition, exposure to some antiretroviral drugs has been shown to be associated with an increased risk of MI $[7,8,9,10,11,12]$. Furthermore, the increased CVD risk noted in HIV-positive individuals may also be related to HIV-related chronic inflammation and immunosuppression $[10,8,13,14,15,16]$. Whilst incidence rates of $M I$ in the HIV-positive population are higher than in the HIVnegative population $[17,18,13]$, there has been a decrease in the rate over time in the D:A:D Study, likely as a result of a more aggressive targeted approach to the management of CVD risk factors [6]. Recent studies have also reported a decreasing trend to the excess MI risk in HIVpositive people compared with the general population in later years $[19,20]$.

Examples of independent predictors of increased mortality after MI in the general population include older age, male sex, in-hospital cardiac complications and no ICP after MIs [21]. Previous findings have shown that HIV-positive individuals admitted for acute coronary syndromes faced a substantial short-term risk of death and an increased risk of coronary revascularization, recurrent MI [22] and all-cause mortality one year after MI [23]. However, few studies have described mortality and clinical outcomes after MI in the HIV-positive population and changes in such outcomes over time. The primary objective of this study was to investigate changes over time in short-term mortality after MI in HIV-positive participants in the D:A:D Study, and possible explanations for any changes seen.

\section{Material and methods}

The D:A:D (Data on Adverse events of antiretroviral Drugs) Study is a large, prospective observational cohort study which follows $>49000 \mathrm{HIV}$-positive persons from 11 collaborating cohorts in Europe, USA and Australia; to date, these persons have contributed $>350000$ personyears of follow-up (PYRS). The primary aim is to investigate associations between the use of antiretroviral drugs and risk of CVD [7]. The data include information on socio-demographic factors, acquired immunodeficiency syndrome (AIDS) events, $\mathrm{CD}^{+}$cell count, HIV viral load, other laboratory results, antiretroviralregimen/treatment history and CVD risk factors/treatments. Data are reported to the D:A:D coordinating centre as anonymous, computerized case report files and then merged into a standardized central dataset. All cases of MI are validated centrally using criteria from the WHO MONICA Study [24] and classified using a Dundee score [24] as definite, possible or unclassifiable and further distinguished into nonfatal and fatal events. In addition, ICPs [coronary artery bypass graft (CABG), carotid angioplasty (ANG) and carotid endarterectomy (END)] are reported. Information on causes of death is collected using a designated Coding of Causes of Death in HIV (CoDe) form (www.chip.dk/code) [25]. This analysis was conducted in accordance with the Declaration of Helsinki and approved by national ethical committee where necessary.

\section{Statistical methods}

All individuals experiencing an MI during prospective follow-up from study initiation in 1999 to February 1, 2014, were identified. Demographic, HIV/CVD-related characteristics and the use of CVD interventions [ICPs, receipt of antiplatelets, angiotensin-converting enzyme inhibitors (ACEIs), other antihypertensives (including beta-blockers) and lipid-lowering drugs (LLDs)] were described at the time of the MI and over the follow-up period. Mortality after MI was described using KaplanMeier methods, with follow-up on individuals who remained alive being right-censored 6 months after their last clinic visit or on 1st February 2014, whichever was earlier. Only the first MI that occurred over follow-up was considered for each individual (although some individuals had experienced their first ever MI prior to enrolment in the study).

Factors associated with overall mortality and mortality from the first month after MI onwards were identified using Cox proportional hazards regression models. Factors (measured at the time of MI) that were considered for inclusion in these models were: age, sex, mode of HIV acquisition, ethnicity, cohort, calendar year of MI, current/cumulative exposure to antiretroviral therapy (ART), prior AIDS diagnosis, $\mathrm{CD}^{+}$cell count, viral load, smoking status, body mass index, family history of CVD, hypertension (SBP $>140 \mathrm{mmHg}$ and/or DBP $>90 \mathrm{mmHg}$ and/or on ACEIs or other antihypertensives [26]), dyslipidaemia [total cholesterol (TC) $\geq 6.2 \mathrm{mmol} / 1$ or hyperdensity lipoprotein cholesterol (HDL-C) $\leq 0.9 \mathrm{mmol} / 1$ or TC:HDL-C ratio $\geq 6.5$ or receipt of LLDs [26]], prior diabetes, prior stroke (both centrally validated), prior MI and Framingham risk score. Factors 
that were associated with mortality in univariable analyses $(P<0.1)$ were considered for inclusion in the multivariable model with a stepwise selection procedure used to identify the factors that would be retained in the model. The resulting model was then further adjusted for interventions received in the first month after MI.

Factors associated with short-term mortality (deaths occurring within the first 31 days after MI) were identified using unadjusted/adjusted logistic regression models with potential confounders selected as described above. All models included calendar year as this was our exposure of interest; analyses were restricted to individuals with at least 1 month of follow-up (or those who had died within the first month) to avoid introducing bias due to variable follow-up times over this first month. Analyses were performed separately for CVD/non-CVD related deaths and stratified by calendar period.

\section{Results}

\section{Characteristics of individuals at time of an MI}

One thousand and eight D:A:D participants experienced an MI over the period 1999-2014. The majority were men $(90.8 \%)$, the median [interquartile range (IQR)] age at the time of MI was $51(44,58)$ years, and $55.9 \%$ were of white ethnicity. The most prevalent CVD risk factors seen were dyslipidemia (66.6\%), current smoking (53.3\%) and hypertension (42.5\%); around one in three individuals with an MI were known to be receiving LLDs (35.5\%) and one in four (26.4\%) antihypertensives. At the time of MI, $90.4 \%$ of the individuals were on ART with only $2.7 \%$ being antiretroviral-naive (the remaining $6.9 \%$ had previously received ART). The median (IQR) 10-year predicted CVD risk (based on the Framingham score, available in $82.1 \%$ of those with an MI) was $14.1 \%$ $(8.9 \%, 20.7 \%) ; 58.2 \%$ of the individuals with an available score had a moderate to high predicted risk of more than 10\% (Table 1).

The number of MIs in each year is shown in Table 1 . The proportion of MIs in each year that was classified as definite MIs was stable $(58.9 \%$ in 1999-2002 to $60.4 \%$ in 2011-2014). There were some changes in the characteristics of individuals that experienced an MI over the same period; the median age increased from 48 to 54 years, the proportion of current smokers increased from 49.5 to $54.6 \%$, and there were increases in the proportions of individuals who had dyslipidemia, hypertension and a moderate/high Framingham risk score. In more recent years, a higher proportion of individuals were on ART, had a suppressed viral load and a higher $\mathrm{CD}^{+}{ }^{+}$cell count (Table 1).

Interventions at or after time of $\mathrm{MI}$

Overall, $581(57.6 \%)$ of the study participants underwent an ANG, 87 (8.6\%) a CABG and 7 (0.7\%) an END following their MI, with 620 (61.5\%) of participants undergoing at least one ICP after MI. Just under twothirds, $370(59.7 \%)$ of the ICPs were carried out on the same day as the MI, 168 (27.1\%) were carried out within the first 31 days and the remaining $82(13.2 \%)$ were carried out more than 31 days after MI. LLDs were initiated after MI in 397 of 650 participants (61.1\%) who were not already receiving them, with 254 (63.9\%) of these initiating LLDs within the first month after MI; antiplatelets, ACEIs and antihypertensives were initiated in 477 of 758 participants (62.9\%) [362 (75.9\%) within the first month after MI], 354 of 810 participants (43.7\%) [202 (57.1\%) within the first month after MI] and 399 of 742 participants $(53.8 \%)$ [265 (66.5\%) within the first month after MI], respectively. In general, there seemed to be an increasing trend over time in the use of medical interventions prior to $\mathrm{MI}$ and in all interventions after MI (Fig. 1).

\section{Causes of death following MI}

Over a median (IQR) follow-up time of 42.7 (9.6, 84.0) months after their MI, 117 of the 1008 HIV-positive individuals (11.6\%) experienced a further MI and 339 (33.6\%) died.

Of the deaths that occurred, 145 (42.8\% of deaths, $14.4 \%$ of all individuals) were on the same day as the MI, 37 (10.7\% of deaths, $3.7 \%$ of all individuals) were within the first month after the MI, and 157 (46.3\% of deaths, 15.6\% of all individuals) were more than 31 days after MI. The proportion of deaths that was due to CVD varied according to the timing of the death relative to the MI: $129(89 \%)$ and $33(87.1 \%)$ of deaths that occurred on the same day as the MI or within the first month after MI were due to CVD respectively, whereas only 59 (37.6\%) of deaths that occurred more than 31 days after MI were due to CVD (Fig. 2a). In total, 182 deaths occurred in the first month after MI yielding an overall short-term mortality rate of $18.1 \%$; this rate dropped from $26.6 \%$ in 1999-2002 to $8.4 \%$ in 2011-2014. The overall proportion of individuals dying from any CVD dropped from $72.6 \%$ in $1999-2002$ to $40.9 \%$ in $2011-2014$, whereas the proportion of individuals dying from causes other than CVD following their MI increased over the same period; major contributing causes being HIV/ AIDS, non-AIDS cancers, bacterial infections, lung disease and unknown causes (Fig. 2b).

\section{Factors associated with overall mortality following MI}

In unadjusted proportional hazards regression models, factors associated with increased mortality were: older age; injection drug use (IDU) mode of HIV acquisition; black African ethnicity; prior AIDS; higher viral load; diabetes; prior MI; and prior stroke. Higher $\mathrm{CD}^{+}{ }^{+}$cell count, later calendar year of MI and family history of CVD were all associated with decreased mortality (data not shown). In a multivariable model, all these factors 


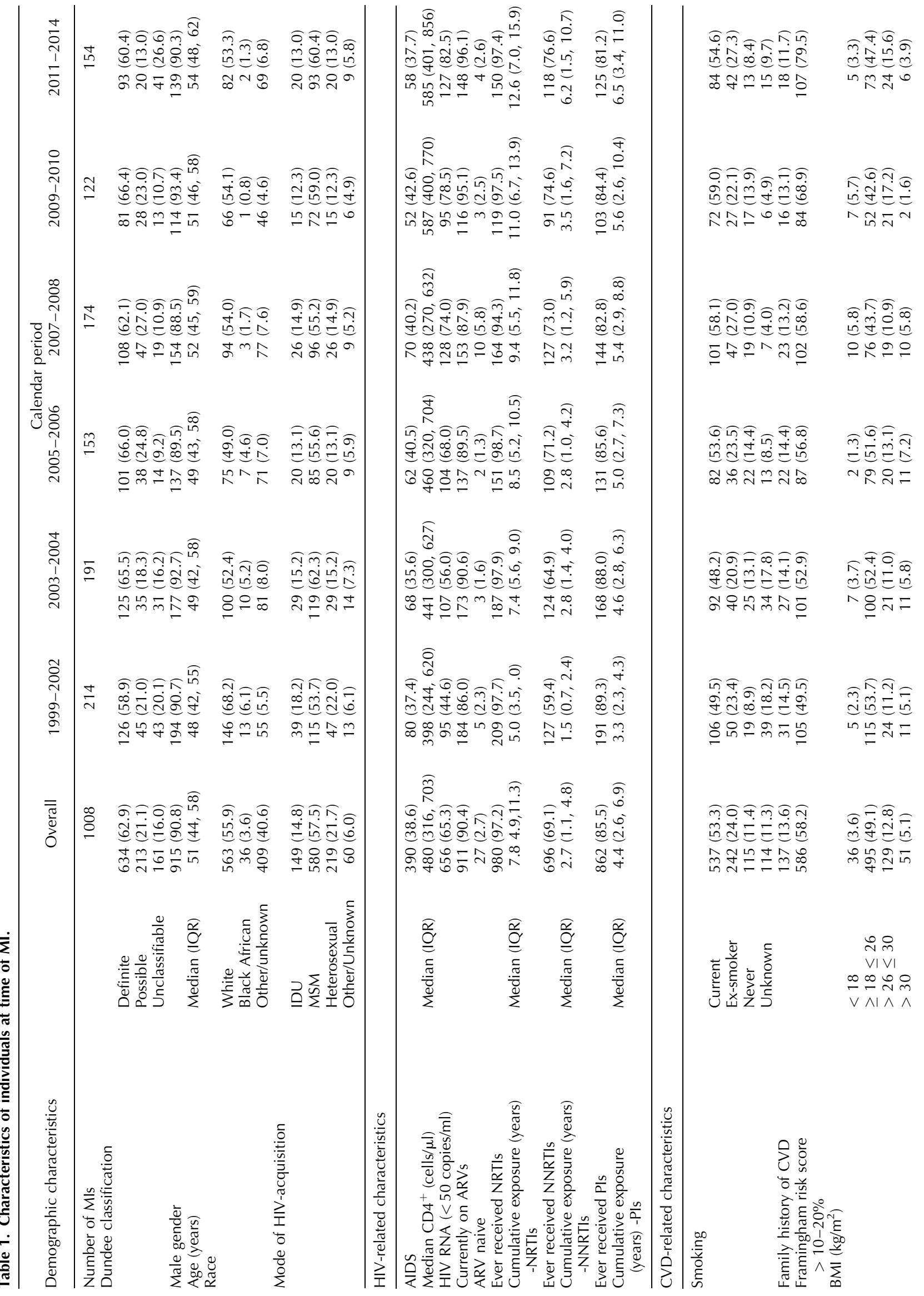




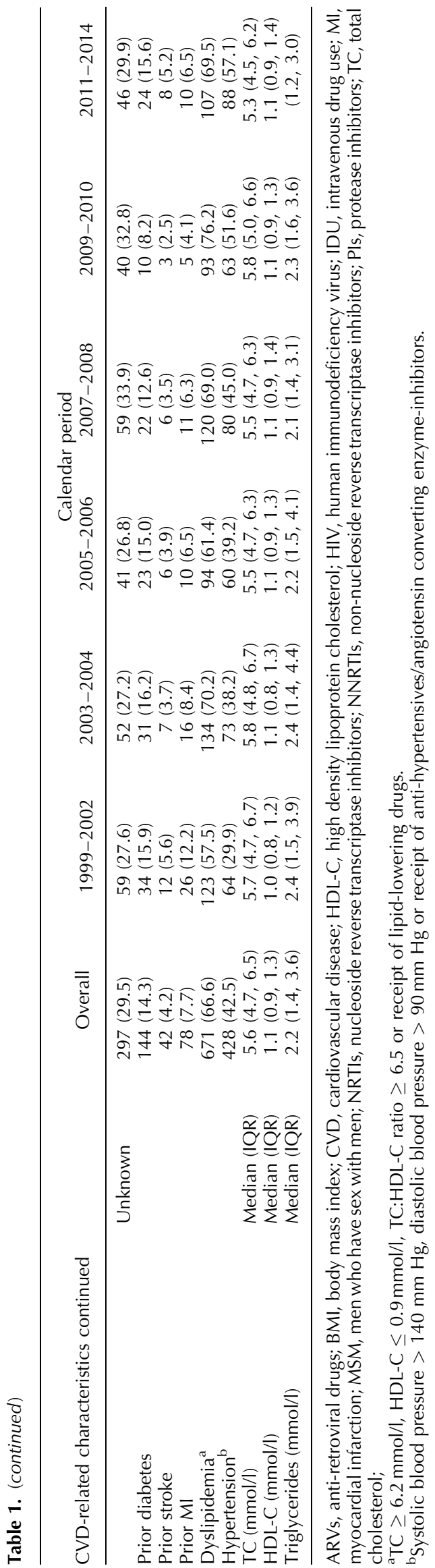

remained independently associated with mortality except black African ethnicity, prior AIDS and higher viral load.

In order to investigate the potential impact of interventions received in the first month post-MI, the analysis was repeated after excluding individuals who did not survive or remain under follow-up beyond the first month. Factors remaining independently associated with mortality in this multivariable model were: older age; prior AIDS; higher viral load; previous MI; diabetes; and later calendar year (Table 2). Additional adjustment for the interventions received in the first month had only minor effects on the associations between these factors and mortality, although it led to an attenuation of the calendar year association from hazard rate 0.95 [95\% confidence interval (CI) 0.89, 1.00] per later year to $0.98(95 \%$ CI $0.92,1.04)$ per later year (Table 2). Of the interventions themselves, only the ICPs demonstrated a strong association with mortality in this model.

\section{Factors associated with short-term mortality following MI}

In unadjusted logistic regression models, the factors associated with an increased risk of short-term mortality were: IDU mode of HIV acquisition; black African ethnicity; prior AIDS; higher viral load and prior stroke. A family history of CVD, higher $\mathrm{CD}^{+}$cell count and later calendar year were associated with decreased risk of short-term mortality (data not shown). In a multivariable model excluding interventions during the first month after MI, IDU mode of HIV acquisition, higher CD4 ${ }^{+}$ cell count, family history of CVD and prior stroke continued to be associated with short-term mortality, and again there was a strong calendar year effect (Table 3). When including interventions received in the first month following MI, ICPs, LLDs and antiplatelets were significantly associated with decreased risk of short-term mortality, and this led to attenuations of the associations with prior stroke [from odds ratio (OR) 3.24 (95\% CI $1.61,6.53)$ to $2.08(95 \% \mathrm{CI} 0.90,4.84)]$ and family history of CVD [from $0.46(95 \% \mathrm{CI} 0.25,0.86)$ to 0.61 (95\% CI $0.30,1.24)]$. The calendar year effect was attenuated from 0.88 (95\% CI $0.83,0.93)$ to 0.97 (95\% CI $0.91,1.02)$ in this adjusted model (Table 3$)$.

\section{Discussion}

We observed an improvement in survival after $\mathrm{MI}$ in the D:A:D cohort over the last 15 years. Those who experienced an MI continued to be individuals with a high CVD risk profile, although their HIV-related health indicators improved. There was an increase in the use of interventions at the time of, and shortly after an MI, and we observed a reduction in the short-term mortality rate 
$\mathrm{ICPS}^{*}$

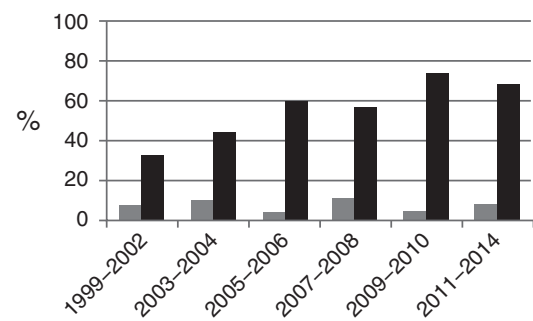

Anti-hypertensives

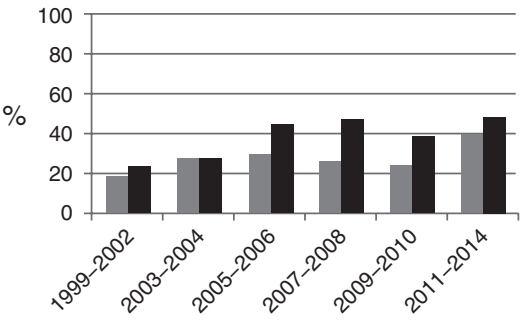

Anti-platelets

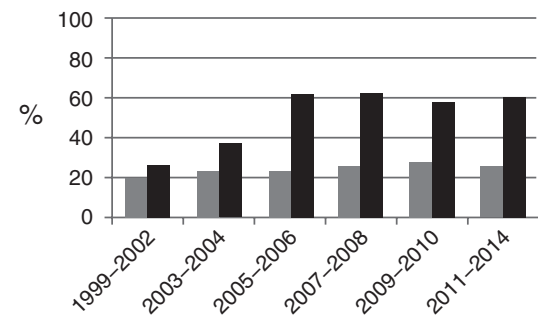

LLDs

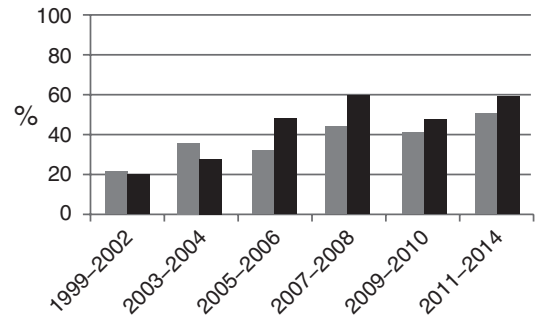

ACEls

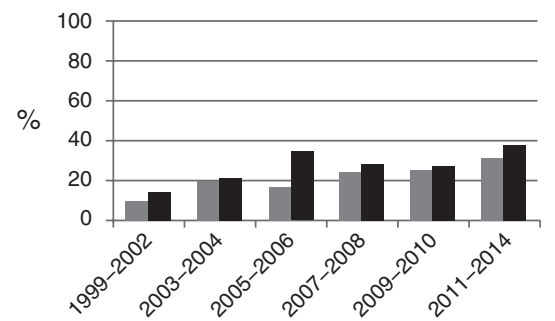

Before MI

After MI

Fig. 1. Use of invasive procedures and drug interventions before and in the first month after MI, stratified by calendar period. ACEls angiotensin-converting enzyme inhibitors; ICPs, invasive cardiovascular procedures; LLDs, lipid-lowering drugs; MI, myocardial infarction. *Carotid angioplasty, coronary artery bypass graft, carotid endarterectomy.

following MI. Predictors of decreased short-term mortality were higher $\mathrm{CD}^{+}$cell count, family history of CVD, later year of $\mathrm{MI}$ and the receipt of antiplatelets, LLDs and ICPs. When adjusting for CVD interventions in the first month after MI, the calendar year effect on short term-mortality was attenuated, arguing that the observed change is mainly driven by the increased use of interventions in recent years.
Within the D:A:D Study, we have seen a gradual reduction in the risk of MI over time in line with findings from the general population [27], and in the present study, we observed some changes in the characteristics of individuals experiencing an MI. As previously documented [28], the key demographic characteristics in individuals at the time of MI were male sex and older age, and other CVD risk factors were dominated by (a)

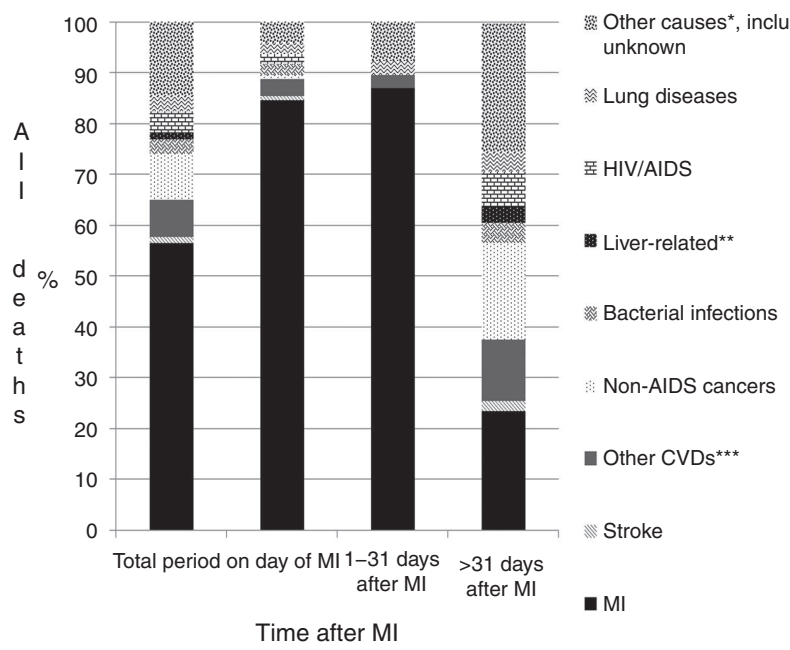

(b)

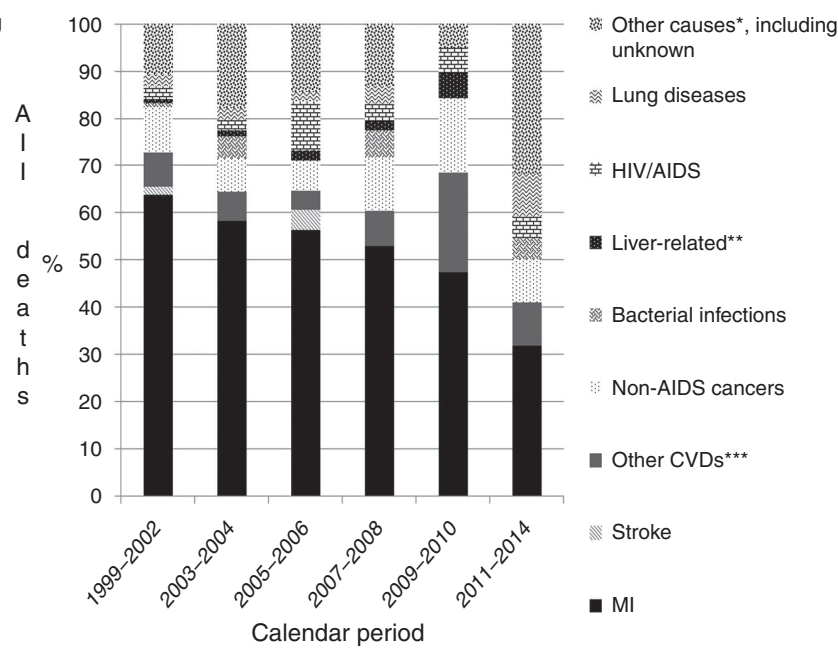

Fig. 2. Causes of death among study participants dying following MI. (a) Overall, stratified by timing of death relative to MI, (b) overall, stratified by calendar period, AIDS/HIV, acquired immunodeficiency syndrome/human immunodeficiency virus; CVDs, cardiovascular diseases; MI, myocardial infarction. *Suicide, psychiatric disease, drug overdose, accident/violent death, nonbacterial infections, pancreatitis, renal failure, gastrointestinal disease, complications due to diabetes, other known/unknown causes. ${ }^{* *}$ Chronic viral hepatitis $\mathrm{B}$ and/or $\mathrm{C}$ and liver failure, $* * *$ Other cardiovascular diseases. 
Table 2. Factors associated with mortality following MI, conditioned on the fact that patient survives for at least one month - multivariable model ${ }^{\mathrm{a}}$.

\begin{tabular}{|c|c|c|c|c|}
\hline \multirow[b]{2}{*}{ Factor } & \multicolumn{2}{|c|}{ Excluding interventions in first month } & \multicolumn{2}{|c|}{ Including interventions in first month } \\
\hline & Hazard rate $(95 \% \mathrm{Cl})$ & $P$-value & Hazard rate $(95 \% \mathrm{Cl})$ & $P$-value \\
\hline Age (/10 years older) & $1.18(1.09,1.28)$ & 0.0001 & $1.13(1.05,1.23)$ & 0.002 \\
\hline AIDS & $1.45(1.05,2.01)$ & 0.02 & $1.42(1.02,1.98)$ & 0.04 \\
\hline $\mathrm{CD}^{+}{ }^{+}$count $(/ 50$ cells/ $\mu$ l increment $)$ & $0.97(0.94,1.00)$ & 0.05 & $0.96(0.93,1.00)$ & 0.03 \\
\hline HIV RNA (/log 10 increment) & $1.19(1.03,1.38)$ & 0.0001 & $1.19(1.02,1.38)$ & 0.03 \\
\hline Previous MI & $1.85(1.14,3.00)$ & 0.02 & $1.63(1.00,2.67)$ & 0.05 \\
\hline Previous diabetes & $2.16(1.46,3.19)$ & 0.01 & $2.13(1.43,3.16)$ & 0.0002 \\
\hline Year of MI (/ later year) & $0.95(0.89,1.00)$ & 0.007 & $0.98(0.92,1.04)$ & 0.50 \\
\hline \multicolumn{5}{|l|}{ Interventions in first month } \\
\hline Anti-platelets & $\mathrm{n} / \mathrm{a}$ & & $0.72(0.44,1.17)$ & 0.18 \\
\hline ACEls & $\mathrm{n} / \mathrm{a}$ & & $1.07(0.65,1.76)$ & 0.80 \\
\hline Anti-hypertensives & $\mathrm{n} / \mathrm{a}$ & & $0.76(0.45,1.29)$ & 0.31 \\
\hline LLDs & $\mathrm{n} / \mathrm{a}$ & & $0.93(0.58,1.49)$ & 0.76 \\
\hline ICPs & $\mathrm{n} / \mathrm{a}$ & & $0.44(0.31,0.63)$ & 0.0001 \\
\hline
\end{tabular}

ACEls, angiotensin converting enzyme- inhibitors; ICPs, invasive cardiovascular procedures; LLDs, lipid-lowering drugs; MI, myocardial infarction. ${ }^{\text {aAlso }}$ adjusted for cohort.

modifiable factors, i.e. current smoking, hypertension and dyslipidemia. There were notable increases in the proportions of people with an MI who were known to have dyslipidemia and/or hypertension, and slight increases in the proportions of individuals with a moderate to high Framingham risk score. Most likely this reflects improved monitoring of lipids and blood pressure in the cohorts rather than any change over time in the risk conferred by these conditions, as well as increased awareness and monitoring of CVD risk and gradual aging of individuals in the cohort, respectively. These findings are consistent with earlier studies $[6,15,29,30,31]$. The proportion of individuals with an MI who were on ART with a suppressed viral load increased, as did the median $\mathrm{CD}^{+}$cell count. This improvement in HIV-related health indices amongst participants in the study has probably contributed to the improved survival seen over the study period. The use of improved antiretroviral drugs with fewer metabolic side- effects in recent years may also partly explain the improved survival, although we did not specifically investigate this in our study.

The HIV-positive population has changed significantly over the last decade as HIV/AIDS-related morbidity and mortality rates have declined and other causes of death have become increasingly common $[32,33,34]$. The allcause mortality rate in the D:A:D Study population fell from $17.5 / 1000$ PYRS in $1999 / 2000$ to $9.1 / 1000$ PYRS in 2009-2011; the leading causes of death being AIDS-and HIV-related causes, non-AIDS defining cancers, liver disease and CVD [32]. The crude CVD incidence mortality rate fell from 1.8/1000 PYRS to 0.9 /1000 PYRS from 1999 to 2011 [32]. In our analysis, nearly $90 \%$ of individuals who died within the first month after MI died of CVD-related causes. Although the short-term mortality rates after MI dropped, our findings emphasize the importance of continued

Table 3. Factors associated with short-term mortality following MI -multivariable model. ${ }^{\mathrm{a}}$

\begin{tabular}{|c|c|c|c|c|}
\hline \multirow[b]{2}{*}{ Factor } & \multicolumn{2}{|c|}{$\begin{array}{l}\text { No adjustment for interventions } \\
\text { in first month }\end{array}$} & \multicolumn{2}{|c|}{$\begin{array}{l}\text { Adjustment for interventions } \\
\text { in first month }\end{array}$} \\
\hline & Odds ratio $(95 \% \mathrm{Cl})$, & $P$-value & Odds ratio $(95 \% \mathrm{Cl})$ & $P$-value \\
\hline IDU & $1.90(1.20,2.99)$ & 0.006 & $1.66(0.98,2.83)$ & 0.06 \\
\hline $\mathrm{CD}^{+}{ }^{+}$count $(/ 50$ cells/ $\mu$ l increment $)$ & $0.93(0.90,0.96)$ & 0.0001 & $0.92(0.89,0.96)$ & 0.0001 \\
\hline Family history of CVD & $0.46(0.25,0.86)$ & 0.01 & $0.61(0.30,1.24)$ & 0.17 \\
\hline Stroke & $3.24(1.61,6.53)$ & 0.001 & $2.08(0.90,4.84)$ & 0.09 \\
\hline Year of MI (/later year) & $0.88(0.83,0.93)$ & 0.0001 & $0.97(0.91,1.02)$ & 0.23 \\
\hline \multicolumn{5}{|l|}{ Interventions in first month } \\
\hline Anti-platelets & $\mathrm{n} / \mathrm{a}$ & & $0.09(0.03,0.31)$ & 0.0001 \\
\hline ACEIs & $\mathrm{n} / \mathrm{a}$ & & $0.45(0.12,1.66)$ & 0.23 \\
\hline Anti-hypertensives & $\mathrm{n} / \mathrm{a}$ & & $0.25(0.05,1.18)$ & 0.08 \\
\hline LLDs & $\mathrm{n} / \mathrm{a}$ & & $0.27(0.08,0.95)$ & 0.04 \\
\hline ICPs & $\mathrm{n} / \mathrm{a}$ & & $0.07(0.04,0.13)$ & 0.0001 \\
\hline
\end{tabular}

ACEls, angiotensin converting enzyme- inhibitors; CVD, cardiovascular disease; ICPs, invasive cardiovascular procedures; LLDs, lipid-lowering drugs; MI, myocardial infarction.

${ }^{a}$ Also adjusted for cohort. 
improvement of the management of CVD in HIVpositive individuals. The magnitude of the reduction in short-term mortality after MI over time in this study (26.6 to $8.4 \%$ ) is similar to the reductions seen in the general population over the last 15-20 years, although mortality is still higher in our study population compared with equally young HIV-negative individuals ( $<65$ years) [1].

The clear improvements in survival outcomes in our study, particularly short-term mortality in the month following MI, appeared to be largely driven by improved clinical management. The use of ICPs increased by 35\% from 1999-2002 to 2011-2014; where ICPs were used, angioplasties in particular tended to be undertaken on the same day as the MI. In some studies, HIV-positive individuals have previously been found to have a higher rate of recurrent MIs and to more frequently undergo urgent angioplasties [18,28,35,36,37]. The proportion of recurrent MIs in the study was $11.6 \%$; which is higher compared with previous findings from the general population (8.9\% in 2010) [38]. We were unable to systematically evaluate the type of MI and degree of vessel disease, but the relatively young median age of the study participants at the time of MI may indicate that a higher proportion may have had a ST-elevated myocardial infarction (STEMI), as an inverse relationship has been demonstrated in men in the general population between age and the likelihood of the MI being a STEMI [39]. A STEMI often requires urgent invasive treatment, possibly partly explaining the increased use of ICPs seen, and the latter may also be explained by the improvement in HIV-related characteristics, increasing the eligibility of individuals to undergo ICPs than was the case in earlier years.

We reported an increasing trend in the use of certain drugs following MI over time; LLDs and antiplatelets were the drugs most frequently started in those not already on these medications, arguing that secondary medical prophylaxis of CVD seem to be somewhat improving. The effectiveness and quality of CVD drugs may have also improved in more recent years, possibly contributing to improved survival.

In our study, we found that the calendar year effect on decreased short-term mortality seemed to be mediated through the increased use of CVD interventions in recent years, as its effect was attenuated after adjusting for interventions received in the first month after MI. Adjustment for interventions did not influence the decreased short-term mortality risk associated with a higher $\mathrm{CD}^{+}$cell count. Similarly, adjustment for interventions received in the first month after MI also resulted in an attenuation of the calendar effect on longterm mortality, again suggesting that this effect was mediated through the use of interventions. Adjusting for interventions in the first month following MI did, however, not influence the predictors of increased longterm mortality, whereas the associations between stroke, family history of CVD and IDU mode of HIV acquisition and short-term mortality were weakened, suggesting also these associations to be partly influenced by the use of interventions.

One study previously demonstrated that HIV status influences long-term risk for adverse outcomes after MI by being an independent predictor for long-term risk of heart failure [40]. In our study, we were unable to assess the impact of HIV per se, but found that survival substantially improved in line with improvements in the $\mathrm{CD} 4^{+}$cell count, which was an independent predictor for decreased short-term mortality. The current longerterm outcomes after MI need to be further explored in our study population.

Although we demonstrated that an increased number of HIV-positive individuals now receive invasive and medical interventions after MI, there is still a proportion of individuals surviving their MIs who do not appear to receive these interventions. One possible explanation is under- or delayed ascertainment of such interventions. However, findings from our annual monitoring process suggest that the number of missed clinical events in the D:A:D Study is very low. Complicating co-morbidities influencing the eligibility of a person to undergo ICPs, the type of MI, and differences in clinical practices at different medical centres may also play a role. Further, the use of drug interventions in those with HIV is often challenging given the possibility of drug-drug interactions with antiretroviral drugs $[6,41]$, which may limit CVD treatment options. Finally, previous findings have reported that there is an inverse relationship between in-hospital mortality after MI and the number of CVD risk factors present at the time of MI [42], indicating that low-risk individuals may therefore have other, as yet unidentified, factors which may contribute to progressive disease [42].

Some limitations to our study need to be acknowledged. The use of nonmedical interventions (e.g. dietary advice, advice on smoking cessation or exercise) is not captured systematically in the D:A:D Study, and may have contributed to improved survival. Further, it is complicated to evaluate the effect of relatively infrequent interventions, such as the use of ICPs, in an observational cohort as analyses of these interventions are likely to be affected by time-varying confounding and standard analytical methods are likely to give biased estimates. Finally, we did not evaluate the status of interventions at time of any recurrent MI although these may also have changed over time.

\section{Conclusion}

In this study, we demonstrated improvements in shortterm survival after MI in HIV-positive individuals, which appeared to be largely driven by increased use of drug 
interventions and ICPs. However, some individuals are still not receiving these interventions despite a high CVD risk profile. Our findings suggest that preventive measures need to be further explored, with targeted focusing on modifiable risk factors including smoking cessation, control of hypertension, dyslipidemia and diabetes as well as appropriate choice of antiretroviral drugs.

\section{Acknowledgements}

Author contributions: L.R., J.D.L. and C.S. developed the initial analysis protocol. L.R and C.I.H. performed study co-ordination and prepared the datasets for analysis, C.S. performed the statistical analysis. C.I.H. prepared the first draft of the manuscript. All authors have provided input at all stages of the project.

Funding: This work was supported by the Highly Active Antiretroviral Therapy Oversight Committee (HAARTOC), a collaborative committee with representation from academic institutions, the European Agency for the Evaluation of Medicinal Products, the United States Food and Drug Administration, the patient community, and pharmaceutical companies with licensed anti-HIV drugs in the European Union: AbbVie, Bristol-Myers Squibb, Gilead Sciences Inc., ViiV Healthcare, Merck \& Co Inc. and Janssen Pharmaceuticals. Supported also by a grant [grant number DNRF126] from the Danish National Research Foundation (CHIP \& PERSIMUNE); by a grant from the Dutch Ministry of Health, Welfare and Sport (ATHENA); by a grant from the Agence nationale de recherches sur le sida et les hépatites virales [ANRS, Action Coordonnée no.7, Cohortes] to the Aquitaine Cohort; The Australian HIV Observational Database (AHOD) is funded as part of the Asia Pacific HIV Observational Database, a program of The Foundation for AIDS Research, amfAR, and is supported in part by a grant from the U.S. National Institutes of Health's National Institute of Allergy and Infectious Diseases (NIAID) [grant number U01-AI069907] and by unconditional grants from Merck Sharp \& Dohme; Gilead Sciences; Bristol-Myers Squibb; Boehringer Ingelheim Roche; Pfizer; GlaxoSmithKline; Janssen Pharmaceuticals. The Kirby Institute is funded by The Australian Government Department of Health and Ageing, and is affiliated with the Faculty of Medicine, The University of New South Wales. By grants from the Fondo de Investigación Sanitaria [grant number FIS 99/0887] and Fundación para la Investigación y la Prevención del SIDA en Espanã [grant number FIPSE 3171/00], to the Barcelona Antiretroviral Surveillance Study (BASS); by the National Institute of Allergy and Infectious Diseases, National Institutes of Health [grants number 5U01AI042170-10, 5U01AI046362-03], to the Terry Beirn Community Programs for Clinical Research on AIDS (CPCRA); by grants from the BIOMED 1 [grant number CT94-1637] and BIOMED 2 [grant number
CT97-2713] programs and the 5th framework program [grant number QLK2-2000-00773], the 6th Framework (LSHP-CT-2006-018632), and the 7th Framework (FP7/2007-2013, EuroCoord no 260694) programmes of the European Commission and unrestricted grants by Janssen R\&D, Merck and Co. Inc., Pfizer Inc., GlaxoSmithKline LLC [the participation of centres from Switzerland is supported by The Swiss National Science Foundation (Grant 108787)] to the EuroSIDA study; by unrestricted educational grants of AbbVie, Bristol-Myers Squibb, Gilead Sciences, GlaxoSmithKline, Pfizer, Janssen Pharmaceuticals to the Italian Cohort Naive to Antiretrovirals (The ICONA Foundation); and by a grant from the Swiss National Science Foundation (grant \#148522) to the Swiss HIV Cohort Study (SHCS).

The content of this publication is solely the responsibility of the authors and does not necessarily represent the official views of any of the institutions mentioned above.

D:A:D particpating cohorts: Aquitaine (France), CPCRA (USA), Nice (France), ATHENA (The Netherlands), EuroSIDA (Europe, Israel and Argentina), SHCS (Switzerland), AHOD (Australia), HIV-BIVUS (Sweden), St. Pierre Brussels Cohort (Belgium), BASS (Spain), The ICONA Foundation (Italy).

D:A:D Steering Committee: Names marked with *, Chair with \#

Members of the D:A:D SC from the Oversight Committee: B. Powderly*, N. Shortman*, C. Moecklinghoff *, G. Reilly*, X. Franquet*. D:A:D Central Coordination: C.I. Hatleberg, L. Ryom, C.A. Sabin*, D. Kamara, C. Smith, A. Phillips*, A. Mocroft, A. Bojesen, J. Nielsen, C. Matthews, D. Raben, J.D. Lundgren. D:A:D data managers: R. Salbøl Brandt (coordinator), M. Rickenbach, I. Fanti, E. Krum, M. Hillebregt, S. Geffard, Jaohar Mourabi, A. Sundström, M. Delforge, E. Fontas, F. Torres, H. McManus, S. Wright, J. Kjær, Dennis Kristensen. Verification of endpoints: A. Sjøl (CVD primary endpoint), P. Meidahl (oncology, new endpoint), J. Helweg-Larsen (hematology, new endpoint), J. Schmidt Iversen (nephrology, new endpoint). Kidney working group: L. Ryom, A. Mocroft, O. Kirk*, P. Reiss*, M. Ross, C.A. Fux, P. Morlat, O. Moranne, A.M. Kesselring, D.A. Kamara, C. Smith, J.D. Lundgren. Mortality working group: C. Smith, L. Ryom, A. Phillips*, R. Weber*, P. Morlat, C. Pradier*, P. Reiss*, N. Friis-Møller, J. Kowalska, J.D. Lundgren. Cancer working group: C. Sabin*, M. Law*, A. d'Arminio Monforte*, F. Dabis*, M. Bruyand, P. Reiss*, C. Smith, D.A. Kamara, M Bower, G. Fätkenheuer, A.Grulich, L.Ryom, J.D. Lundgren.

The members of the 11 cohorts are as follows:

ATHENA (AIDS Therapy Evaluation Project Netherlands) - Central coordination: P. Reiss*, S. Zaheri, M 
Hillebregt, L.Gras. Participating physicians (oSite coordinating physicians) - Academisch Medisch Centrum bij de Universiteit van Amsterdam, Amsterdam: Prof. Dr J.M. Prins $₫$, Prof. Dr T.W. Kuijpers, Drs H.J. Scherpbier, J.T.M. van der Meer, F.W.M.N. Wit, M.H. Godfried, Prof. Dr P. Reiss a*, Prof. Dr T. van der Poll, Dr F.J.B. Nellen, Prof. Dr J.M.A. Lange, Drs S.E. Geerlings, M. van Vugt, D. Pajkrt, J.C. Bos, M. van der Valk, M.L. Grijsen, W.J. Wiersinga, A. Goorhuis, J.W.R. Hovius. Academisch Ziekenhuis Maastricht, Maastricht: Drs S. Lowea, A. Oude Lashof, D. Posthouwer. Catharinaziekenhuis, Eindhoven: Drs M.J.H. Pronko, H.S.M. Ammerlaan. Erasmus Medisch Centrum, Rotterdam: Drs M.E. van der Endea, T.E.M.S. de Vries-Sluijs, C.A.M. Schurink, J.L. Nouwen, A. Verbon, B.J.A. Rijnders, E.C.M. van Gorp, M. van der Feltz. Erasmus Medisch Centrum-Sophia, Rotterdam: Drs G.J.A. Driessen, A.M.C. van Rossum. Flevoziekenhuis. Almere: Dr J. Brangero. HagaZiekenhuis, Den Haag: Drs E.F. Schippers $\propto$, C. van Nieuwkoop, E.P. van Elzakker. Isala Klinieken, Zwolle: Drs P.H.P. Groenevelda, J.W. Bouwhuis. Kennemer Gasthuis: Dr R. Soetekouwd, Prof. Dr R.W. ten Kate. Leids Universitair Medisch Centrum, Leiden: Dr F.P. Kroon a, Prof. Dr J.T. van Dissel, Drs S.M. Arend, M.G.J. de Boer, H. Jolink, H.J.M. ter Vollaard, M.P. Bauer. Maasstadziekenhuis, Rotterdam: Drs J.G. den Hollandera, K. Pogany. Medisch Centrum Alkmaar, Alkmaar: Dr G. van Twillert, , Dr W. Kortmann, , Dr J.W.T. Cohen Stuart, Dr B.M.W. Diederen. Medisch Centrum Haaglanden, Den Haag: Dr E.M.S. Leyten, , Dr L.B.S. Gelinck. Medisch Spectrum Twente, Enschede: Dr G.J. Kootstra $\mathrm{Q}$, Dr C.E. Delsing. Onze Lieve Vrouwe Gasthuis, Amsterdam: Prof. Dr K. Brinkman a, Dr W.L. Blok, Dr P.H.J. Frissen, Dr W.E.M. Schouten, Dr G.E.L. van den Berk. Sint Elisabeth Ziekenhuis, Tilburg: Dr M.E.E. van Kasteren $\not$, Dr A.E. Brouwer. Sint Lucas Andreas Ziekenhuis, Amsterdam: Dr J. Veenstra $\propto$, Dr K.D. Lettinga. Slotervaartziekenhuis, Amsterdam: Dr J.W. Muldera, Dr S.M.E. Vrouenraets, Dr F.N. Lauw. Stichting Medisch Centrum Jan van Goyen, Amsterdam: Dr A. van Eeden,, , Dr D.W.M. Verhagen. Universitair Medisch Centrum Groningen, Groningen: Dr H.G. Sprenger,, Dr R. Doedens, Dr E.H. Scholvinck, Dr S. van Assen, Dr W.F.W. Bierman. Universitair Medisch Centrum Sint Radboud, Nijmegen: Dr P.P. Koopmans $\alpha$, Dr M. Keuter, Dr A.J.A.M. van der Ven, Dr H.J.M. ter Hofstede, Dr A.S.M. Dofferhoff, Dr A Warris, Dr R. van Crevel. Universitair Medisch Centrum Utrecht, Utrecht: Prof. Dr A.I.M. Hoepelmana, Dr T. Mudrikova, Dr M.M.E. Schneider, Dr P.M. Ellerbroek, Dr J.J. Oosterheert, Dr J.E. Arends, Dr M.W.M. Wassenberg, Dr R.E. Barth. Vrije Universiteit Amsterdam, Amsterdam: Dr M.A. van Agtmaelo, Dr R.M. Perenboom, Dr F.A.P. Claessen, Dr M. Bomers, Dr E.J.G. Peters. Wilhelmina Kinderziekenhuis, Utrecht: Dr S.P.M. Geelen, Dr T.F.W. Wolfs, Dr L.J. Bont. Ziekenhuis Rijnstate, Arnhem: Dr C. Richtera, Dr J.P. van der Berg, Dr E.H. Gisolf.
Admiraal De Ruyter Ziekenhuis, Vlissingen: Dr M. van den Bergea, Dr A. Stegeman. Medisch Centrum Leeuwarden, Leeuwarden: Dr M.G.A. van Vonderen $₫$, Dr D.P.F. van Houte. Medisch Centrum Zuiderzee, Lelystad: Dr S. Weijero, Dr R. el Moussaoui. Sint Elisabeth Hospitaal, Willemstad - Curaçao: Dr C. Winkel, Dr F. Muskiet, Dr Durand, Dr R. Voigt. Aquitaine Cohort (France) Coordination: F. Bonnet, F. Dabis. Scientific committee: F. Bonnet, S. Bouchet, D. Breilh, G. Chêne, F. Dabis, M. Dupon, H. Fleury, V. Gaborieau, D. Lacoste, D. Malvy, P. Mercié, P. Morlat, D. Neau, I. Pellegrin, JL. Pellegrin, S. Reigadas, S. Tchamgoué. Epidemiology and Methodology: M. Bruyand, G. Chêne, F. Dabis, C. Fagard, S. LawsonAyayi, L. Richert, R. Thiébaut, L. Wittkop. Infectious Diseases and Internal Medicine: K. André, F. Bonnet, N. Bernard, L. Caunègre, C. Cazanave, J. Ceccaldi, I. Chossat, C. Courtault, FA. Dauchy, S. De Witte, D. Dondia, M. Dupon, A. Dupont, P. Duffau, H. Dutronc, S. Farbos, I. Faure, V. Gaborieau, Y. Gerard, C. Greib, M. Hessamfar-Joseph, Y. Imbert, D. Lacoste, P. Lataste, E. Lazaro, D. Malvy, J. Marie, M. Mechain, JP. Meraud, P. Mercié, E. Monlun, P. Morlat, D. Neau, A. Ochoa, JL. Pellegrin, M. Pillot-Debelleix, T. Pistone, I. Raymond, MC. Receveur, P. Rispal, L. Sorin, S. Tchamgoué, C. Valette, MA. Vandenhende, MO. Vareil, JF. Viallard, H. Wille, G. Wirth. Immunology: J.F. Moreau, I. Pellegrin. Virology: H. Fleury, M.E. Lafon, S. Reigadas, P. Trimoulet. Pharmacology: S. Bouchet, D. Breilh, F. Haramburu, G. Miremont-Salamé. Data collection, Project Management and Statistical Analyses: M.J. Blaizeau, I. Crespel, M. Decoin, S. Delveaux, F. Diarra, C. D'Ivernois, C. Hanappier, D. Lacoste, S. LawsonAyayi, O. Leleux, F. Le Marec, E. Lenaud, J. Mourali, E. Pernot, A. Pougetoux, B. Uwamaliya-Nziyumvira, A. Tsaranazy, A. Valdes. IT department and eCRF development: V. Conte, I. Louis, G. Palmer, V. Sapparrart, D. Touchard. AHOD (Australian HIV Observational Database, Australia): Central coordination: M. Law *, K. Petoumenos, H. McManus, S. Wright, C. Bendall (Sydney, New South Wales). Participating physicians (city, state): R. Moore, S. Edwards, J. Hoy, K. Watson, N. Roth, J. Nicholson (Melbourne, Victoria); M. Bloch, T. Franic, D. Baker, R. Vale, A. Carr, D. Cooper (Sydney, New South Wales); J. Chuah, M. Ngieng (Gold Coast, Queensland), D. Nolan, J. Skett (Perth, Western Australia). BASS (Spain): Central coordination: G. Calvo, F. Torres, S. Mateu (Barcelona). Participating physicians (city): P. Domingo, M.A. Sambeat, J. Gatell, E. Del Cacho, J. Cadafalch, M. Fuster (Barcelona); C. Codina, G. Sirera, A. Vaqué (Badalona). The Brussels St. Pierre Cohort (Belgium). Coordination: S. De Wit*, N. Clumeck, M. Delforge, C. Necsoi. Participating physicians: N. Clumeck, S. De Wit*, A.F. Gennotte, M. Gerard, K. Kabeya, D. Konopnicki, A. Libois, C. Martin, M.C. Payen, P. Semaille, Y. Van Laethem. CPCRA (USA): Central coordination: J. Neaton, G. Bartsch, W.M. El-Sadr*, E. Krum, G. Thompson, D. Wentworth. 
Participating physicians (city, state): R. Luskin-Hawk (Chicago, Illinois); E. Telzak (Bronx, New York); W.M. El-Sadr (Harlem, New York); D.I. Abrams (San Francisco, California); D. Cohn (Denver, Colorado); N. Markowitz (Detroit, Michigan); R. Arduino (Houston, Texas); D. Mushatt (New Orleans, Louisiana); G. Friedland (New Haven, Connecticut); G. Perez (Newark, New Jersey); E. Tedaldi (Philadelphia, Pennsylvania); E. Fisher (Richmond, Virginia); F. Gordin (Washington, DC); L.R. Crane (Detroit, Michigan); J. Sampson (Portland, Oregon); J. Baxter (Camden, New Jersey). EuroSIDA (multinational) Coordinating Centre: J Lundgren\#, O Kirk*, A Mocroft, A Cozzi-Lepri, D Grint, D Podlekareva, J Kjær, L Peters, J Reekie, J Kowalska, J Tverland, A H Fischer, J Nielsen Participating countries and physicians Argentina: (M Losso), C Elias, Hospital JM Ramos Mejia, Buenos Aires. Austria: (N Vetter), Pulmologisches Zentrum der Stadt Wien, Vienna; R Zangerle, Medical University Innsbruck, Innsbruck. Belarus: (I Karpov), A Vassilenko, Belarus State Medical University, Minsk, VM Mitsura, Gomel State Medical University, Gomel; O Suetnov, Regional AIDS Centre, Svetlogorsk. Belgium: (N Clumeck), S De Wit*, M Delforge, Saint-Pierre Hospital, Brussels; R Colebunders, Institute of Tropical Medicine, Antwerp; L Vandekerckhove, University Ziekenhuis Gent, Gent. Bosnia-Herzegovina: (V Hadziosmanovic), Klinicki Centar Univerziteta Sarajevo, Sarajevo. Bulgaria: (K Kostov), Infectious Diseases Hospital, Sofia. Croatia: (J Begovac), University Hospital of Infectious Diseases, Zagreb. Czech Republic: (L Machala), D Jilich, Faculty Hospital Bulovka, Prague; D Sedlacek, Charles University Hospital, Plzen. Denmark: (J Nielsen), G Kronborg, $\mathrm{T}$ Benfield, $\mathrm{M}$ Larsen, Hvidovre Hospital, Copenhagen; J Gerstoft, T Katzenstein, A-B E Hansen, P Skinhøj, Rigshospitalet, Copenhagen; C Pedersen, Odense University Hospital, Odense; L Ostergaard, Skejby Hospital, Aarhus. Estonia: (K Zilmer), WestTallinn Central Hospital, Tallinn; Jelena Smidt, Nakkusosakond Siseklinik, Kohtla-Järve. Finland: (M Ristola), Helsinki University Central Hospital, Helsinki. France: (C Katlama), Hôpital de la Pitié-Salpétière, Paris; J-P Viard, Hôpital Necker-Enfants Malades, Paris; P-M Girard, Hospital Saint-Antoine, Paris; JM Livrozet, Hôpital Edouard Herriot, Lyon; P Vanhems, University Claude Bernard, Lyon; C Pradier, Hôpital de l'Archet, Nice; F Dabis*, D Neau, Unité INSERM, Bordeaux. Germany: (J Rockstroh), Universitäts Klinik Bonn; R Schmidt, Medizinische Hochschule Hannover; J van Lunzen, O Degen, University Medical Center HamburgEppendorf, Infectious Diseases Unit, Hamburg; HJ Stellbrink, IPM Study Center, Hamburg; S Staszewski, JW Goethe University Hospital, Frankfurt; Markus Bickel, Medizinische Poliklinik, Munich; G. Fätkenheuer, Universität Köln, Cologne. Greece: (J Kosmidis), P Gargalianos, G Xylomenos, J Perdios, Athens General Hospital; G Panos, A Filandras, E Karabatsaki, 1st IKA Hospital; H Sambatakou, Ippokration Genereal Hospital,
Athens. Hungary: (D Banhegyi), Szent Lásló Hospital, Budapest. Ireland: (F Mulcahy), St. James's Hospital, Dublin. Israel: (I Yust), D Turner, M Burke, Ichilov Hospital, Tel Aviv; S Pollack, G Hassoun, Rambam Medical Center, Haifa; S Maayan, Hadassah University Hospital, Jerusalem. Italy: (S Vella), Istituto Superiore di Sanità, Rome; R Esposito, I Mazeu, C Mussini, Università Modena, Modena; C Arici, Ospedale Riuniti, Bergamo; R Pristera, Ospedale Generale Regionale, Bolzano; F Mazzotta, A Gabbuti, Ospedale S Maria Annunziata, Firenze; V Vullo, M Lichtner, University di Roma la Sapienza, Rome; A Chirianni, E Montesarchio, M Gargiulo, Presidio Ospedaliero AD Cotugno, Monaldi Hospital, Napoli; G Antonucci, A Testa, P Narciso, C Vlassi, M Zaccarelli, Istituto Nazionale Malattie Infettive Lazzaro Spallanzani, Rome; A Lazzarin, A Castagna, N Gianotti, Ospedale San Raffaele, Milan; M Galli, A Ridolfo, Osp. L. Sacco, Milan; A d'Arminio Monforte*, Istituto Di Clinica Malattie Infettive e Tropicale, Milan. Latvia: (B Rozentale), I Zeltina, Infectology Centre of Latvia, Riga. Lithuania: (S Chaplinskas), Lithuanian AIDS Centre, Vilnius. Luxembourg: (R Hemmer), $\mathrm{T}$ Staub, Centre Hospitalier, Luxembourg. Netherlands: (P Reiss*), Academisch Medisch Centrum bij de Universiteit van Amsterdam, Amsterdam. Norway: (V Ormaasen), A Maeland, J Bruun, Ullevål Hospital, Oslo. Poland: (B Knysz) J Gasiorowski, Medical University, Wroclaw; A Horban, E Bakowska, Centrum Diagnostyki i Terapii AIDS, Warsaw; A Grzeszczuk, R Flisiak, Medical University, Bialystok; A Boron-Kaczmarska, M Pynka, M Parczewski, Medical Univesity, Szczecin; M Beniowski, E Mularska, Osrodek Diagnostyki i Terapii AIDS, Chorzow; H Trocha, Medical University, Gdansk; E Jablonowska, E Malolepsza, K Wojcik, Wojewodzki Szpital Specjalistyczny, Lodz. Portugal: (F Antunes), M Doroana, L Caldeira, Hospital Santa Maria, Lisbon; K Mansinho, Hospital de Egas Moniz, Lisbon; F Maltez, Hospital Curry Cabral, Lisbon. Romania: (D Duiculescu), Spitalul de Boli Infectioase si Tropicale: Dr Victor Babes, Bucarest. Russia: (A Rakhmanova), Medical Academy Botkin Hospital, St Petersburg; N Zakharova, St Petersburg AIDS Centre, St Peterburg; S Buzunova, Novgorod Centre for AIDS, Novgorod. Serbia: (D Jevtovic), The Institute for Infectious and Tropical Diseases, Belgrade. Slovakia: (M Mokráš), D Staneková, Dérer Hospital, Bratislava. Slovenia: (J Tomazic), University Clinical Centre Ljubljana, Ljubljana. Spain: (J González-Lahoz), V Soriano, P Labarga, J Medrano, Hospital Carlos III, Madrid; S Moreno, JM Rodriguez, Hospital Ramon y Cajal, Madrid; B Clotet, A Jou, R Paredes, C Tural, J Puig, I Bravo, Hospital Germans Trias i Pujol, Badalona; JM Gatell, JM Miró, Hospital Clinic i Provincial, Barcelona; P Domingo, M Gutierrez, G Mateo, MA Sambeat, Hospital Sant Pau, Barcelona. Sweden: (A Karlsson), Venhaelsan-Sodersjukhuset, Stockholm; L Flamholc, Malmö University Hospital, Malmö. Switzerland: (B Ledergerber), R Weber*, University Hospital, Zürich; P Francioli, M Cavassini, 
Centre Hospitalier Universitaire Vaudois, Lausanne; B Hirschel, E Boffi, Hospital Cantonal Universitaire de Geneve, Geneve; H Furrer, Inselspital Bern, Bern; M Battegay, L Elzi, University Hospital Basel. Ukraine: (E Kravchenko), N Chentsova, Kiev Centre for AIDS, Kiev; V Frolov, G Kutsyna, Luhansk State Medical University; Luhansk; S Servitskiy, Odessa Region AIDS Center, Odessa; M Krasnov, Kharkov State Medical University, Kharkov. United Kingdom: (S Barton), St. Stephen's Clinic, Chelsea and Westminster Hospital, London; AM Johnson, D Mercey, Royal Free and University College London Medical School, London (University College Campus); A Phillips, MA Johnson, A Mocroft, Royal Free and University College Medical School, London (Royal Free Campus); M Murphy, Medical College of Saint Bartholomew's Hospital, London; J Weber, G Scullard, Imperial College School of Medicine at St. Mary's, London; M Fisher, Royal Sussex County Hospital, Brighton; C Leen, Western General Hospital, Edinburgh. HivBivus (Sweden): Central coordination: L. Morfeldt, G. Thulin, A. Sundström. Participating physicians (city): B. Åkerlund (Huddinge); K. Koppel, A. Karlsson (Stockholm); L. Flamholc, C. Håkangård (Malmö). The ICONA Foundation (Italy): Board of directors: A d'Arminio Monforte*, (Chair), M Andreoni, G Angarano, A Antinori, F Castelli, R Cauda, G Di Perri, M Galli, R Iardino, G Ippolito, A Lazzarin, CF Perno, F von Schloesser, P Viale. Scientific secretary: A d'Arminio Monforte, A Antinori, A Castagna, F CeccheriniSilberstein, A Cozzi-Lepri, E Girardi, S Lo Caputo, C Mussini, M Puoti. Steering committee: M Andreoni, A Ammassari, A Antinori, C Balotta, A Bandera, P Bonfanti, S Bonora, M Borderi, A Calcagno, L Calza, MR Capobianchi, A Castagna, F Ceccherini-Silberstein, A Cingolani, P Cinque, A Cozzi-Lepri, A d'Arminio Monforte, A De Luca, A Di Biagio, E Girardi, N Gianotti, A Gori, G Guaraldi, G Lapadula, M Lichtner, S Lo Caputo, G Madeddu, F Maggiolo, G Marchetti, S Marcotullio, L Monno, C Mussini, S Nozza, M Puoti, E Quiros Roldan, R Rossotti, S Rusconi, MM Santoro, A Saracino, M Zaccarelli. Statistical and monitoring team: A Cozzi-Lepri, I Fanti, L Galli, P Lorenzini, A Rodano, M Shanyinde, A Tavelli. Participating physicians and centres: A Giacometti, A Costantini, S Mazzoccato (Ancona); G Angarano, L Monno, C Santoro (Bari); F Maggiolo, C Suardi (Bergamo); P Viale, E Vanino, G Verucchi (Bologna); F Castelli, E Quiros Roldan, C Minardi (Brescia); T Quirino, C Abeli (Busto Arsizio); PE Manconi, P Piano (Cagliari); J Vecchiet, K Falasca (Chieti); L Sighinolfi, D Segala (Ferrara); F Mazzotta, S Lo Caputo (Firenze); G Cassola, C Viscoli, A Alessandrini, R Piscopo, G Mazzarello (Genova); C Mastroianni, V Belvisi (Latina); P Bonfanti, I Caramma (Lecco); A Chiodera, AP Castelli (Macerata); M Galli, A Lazzarin, G Rizzardini, M Puoti, A d'Arminio Monforte, AL Ridolfo, R Piolini, A Castagna, S Salpietro, L Carenzi, MC Moioli, C Tincati, G. Marchetti (Milano); C Mussini, C Puzzolante (Modena); A Gori, G Lapadula
(Monza); N Abrescia, A Chirianni, G Borgia, F Di Martino, L Maddaloni, I Gentile, R Orlando (Napoli); F Baldelli, D Francisci (Perugia); G Parruti, T Ursini (Pescara); G Magnani, MA Ursitti (Reggio Emilia); R Cauda, M Andreoni, A Antinori, V Vullo, A Cingolani, G Baldin, L Gallo, E Nicastri, R Acinapura, M Capozzi, R Libertone, S Savinelli, M Zaccarelli (Roma); M Cecchetto, F Viviani (Rovigo); MS Mura, G Madeddu (Sassari); A De Luca, B Rossetti (Siena); P Caramello, G Di Perri, GC Orofino, S Bonora, M Sciandra (Torino); M Bassetti, A Londero (Udine); G Pellizzer, V Manfrin (Vicenza).

Nice HIV Cohort (France):

Central coordination: C. Pradier*, E. Fontas, K. Dollet, C. Caissotti. Participating physicians: P. Dellamonica, E. Bernard, E. Cua, F. De Salvador-Guillouet, J. Durant, S. Ferrando, V. Mondain-Miton, A. Naqvi, I. Perbost, B. Prouvost-Keller, S. Pillet, P. Pugliese, V. Rahelinirina, P.M. Roger. SHCS (Swiss HIV Cohort Study, Switzerland): V Aubert, M Battegay, E Bernasconi, J Böni, HC Bucher, C Burton-Jeangros, A Calmy, M Cavassini, G Dollenmaier, M Egger, L Elzi, J Fehr, J Fellay, H Furrer (Chairman of the Clinical and Laboratory Committee), CA Fux, M Gorgievski, H Günthard (President of the SHCS), D Haerry (deputy of "Positive Council"), B Hasse, HH Hirsch, M Hoffmann, I Hösli, C Kahlert, L Kaiser, O Keiser, T Klimkait, R Kouyos, H Kovari, B Ledergerber, G Martinetti, B Martinez de Tejada, K Metzner, N Müller, D Nadal, D Nicca, G Pantaleo, A Rauch (Chairman of the Scientific Board), S Regenass, M Rickenbach (Head of Data Center), C Rudin (Chairman of the Mother \& Child Substudy), F Schöni-Affolter, P Schmid, J Schüpbach, R Speck, P Tarr, A Telenti, A Trkola, P Vernazza, R Weber*, $\mathrm{S}$ Yerly. Ethics committee approval: This analysis was conducted in accordance with the Declaration of Helsinki and approved by national ethical committee where necessary.

\section{Conflicts of interest}

C.I.H., L.R., J.D.L., W.E.-S., F.D., S.D.W. and E.F. have no conflicts of interest. C.Smith has received sponsorship for the preparation of educational materials from Gilead Sciences, Bristol Myers Squibb and ViiV Pharmeceuticals. C.Smith has also attended an advisory board for Gilead Sciences. R.W. has received travel grants from Abbott, Boehringer Ingelheim, Bristol-Myers Squibb, Gilead Sciences, GlaxoSmithKline, Merck Sharp \& Dome, Pfizer, Roche, TRB Chemedica and Tibotec. R.W.'s institution has received unrestricted educational grants from GlaxoSmithKline, ViiV, and Gilead Sciences. P.R. has through his institution received independent scientific grant support from Gilead Sciences, Janssen Pharmaceuticals Inc, Merck \& Co, Bristol-Myers Squibb and ViiV Healthcare; he served on scientific advisory board for Gilead Sciences; he serves on data safety 
monitoring committee for Janssen Pharmaceuticals Inc; chaired a scientific symposium by ViiV Healthcare, for which his institution has received remuneration. M.L. has received unrestricted research grants from Boehringer Ingelheim, Gilead Sciences, Merck Sharp \& Dohme, Bristol-Myers Squibb, Janssen-Cilag, and ViiV HealthCare, and DSMB siting fees from Sirtex Pty Ltd. A.D.A.M. has received grants for Advisory boards by Abbvie, BMS, Janssen, Gilead, MSD, ViiV Italy. A.d'A.M.'s institution has received grants for research from Gilead, Janssen, ViiV. A.M. has received honoraria, lecture fees or travel grants from Merck, BMS, Gilead, $\mathrm{BI}$, Pfizer and Wragge LLC. A.P. has been speaking at national meetings sponsored by Gilead, attended Abbvie Advisory Board and Consultancy with GSK Biologicals. All of these are in the past 3 years but none are ongoing. C.Sabin has received funding for membership of Data Safety and Monitoring Boards, Advisory Boards, for the preparation of educational materials and for membership of speaker bureaux from Gilead Sciences, ViiV Healthcare, Janssen-Cilag and BristolMyers Squibb.

This project was presented at CROI 3-6 of March 2013, Atlanta, GA, USA.

\section{References}

1. Nguyen HL, Saczynski JS, Gore JM, Waring ME, Lessar D, Yarzebski J, et al. Long-term trends in short-term outcomes in acute myocardial infarction. Am / Med 2011; 124:939-946.

2. Ford ES, Ajani UA, Croft JB, Crithchley JA, Labarte DR, Kottke $\mathrm{TE}$, et al. Explaining the decrease in U.S. deaths from coronary disease, 1980-2000. N Engl J Med 2007; 356:2388-2398.

3. Mondy K, Overton ET, Grubb J, Tong S, Seyfried W, Powderly W, et al. Metabolic syndrome in HIV-infected patients from an urban, midwestern US outpatient population. Clin Infect Dis 2007; 44:726-734.

4. Perelló R, Calvo M, Miró O, Castañeda M, Saubí N, Camón S, et al. Clinical presentation of acute coronary syndrome in HIV infected adults: a retrospective analysis of a prospectively collected cohort. Eur J Intern Med 2011; 22:485-488.

5. Glass TR, Ungsedhapand C, Wolbers M, Weber R, Vernazza PL, Rickenbach $M$, et al. Prevalence of risk factors for cardiovascular disease in HIV-infected patients over time: the Swiss HIV Cohort Study. HIV Med 2006; 7:404-410.

6. Sabin C, d'Arminio Monforte A, Friis-Moller N, Weber R, El-Sadr WM, Reiss $P$, et al. Changes over time in risk factors for cardiovascular disease and use of lipid-lowering drugs in HIV-infected individuals and impact on myocardial infarction. Clin Infect Dis 2008; 46:1101-1110.

7. Friis-Moller N, Sabin C, Weber R, d'Arminio Monforte A, El-Sadr WM, Reiss P, et al. Adverse Events of Anti-HIV Drugs (DAD) Study Group. Combination antiretroviral therapy and the risk of myocardial infarction. N Engl / Med 2003; 349:1993-2003.

8. Obel N, Thomsen HF, Kronborg G, Larsen CS, Hildebrandt PR, Sørensen HT, et al. Ischemic heart disease in HIV-infected and HIV-uninfected individuals: a population-based cohort study. Clin Infect Dis 2007; 44:1625-1631.

9. Lang S, Mary-Krause M, Cotte L, Gilquin J, Partisani M, Simon A, et al. for the French Hospital database on HIV-ANRS CO4. Impact of individual antiretroviral drugs on the risk of myocardial infarction in human immunodeficiency virus-infected patients: a case-control study nested within the French Hospital Database on HIV ANRS cohort CO4. Arch Intern Med 2010; 170:1228-1238.
10. Friis-Møller N, Reiss P, Sabin C, Weber R, d'Arminio Monforte $\mathrm{A}, \mathrm{El}$-Sadr W, et al. Class of antiretroviral drugs and the risk of myocardial infarction. N Engl J Med 2007; 356:1723-1735.

11. Sabin C, Worm SW, Weber R, Reiss P, El-Sadr W, Dabis F, et al. Use of nucleoside reverse transcriptase inhibitors and risk of myocardial infarction in HIV-infected patients enrolled in the D: A: D study: a multicohort collaboration. Lancet 2008; 371:1417-1426.

12. Worm SW, Sabin C, Weber R, Reiss P, El-Sadr W, Dabis F, et al. Risk of myocardial infarction in patients with HIV infection exposed to specific individual antiretroviral drugs from the 3 major drug classes: the data collection on adverse events of anti-HIV drugs (D:A:D) study. J Infect Dis 2010; 201:318-330.

13. Triant VA, Lee H, Hadigan C, Grinspoon SK. Increased acute myocardial infarction rates and cardiovascular risk factors among patients with human immunodeficiency virus disease. J Clin Endocrinol Metab 2007; 92:2506-2512.

14. Mary-Krause M, Cotte L, Simon A, Partisani M, Costagliola D. Increased risk of myocardial infarction with duration of protease inhibitor therapy in HIV-infected men. AIDS 2003; 17:2479-2486.

15. Savès $M$, Chêne $G$, Ducimetière $P$, Leport $C$, le Moal G, Amouyel $\mathrm{P}$, et al. Risk factors for coronary heart disease in patients treated for human immunodeficiency virus infection compared with the general population. Clin Infect Dis 2003; 37:292-298.

16. Hsue PY, Hunt PW, Sinclair E, Bredt B, Franklin A, Killian M, et al. Increased carotid intima-media thickness in HIV patients is associated with increased cytomegalovirus-specific T-cell responses. AIDS 2006; 20:2275-2283.

17. Lang S, Mary-Krause M, Cotte L, Gilquin J, Partisani M, Simon A, et al. Increased risk of myocardial infarction in HIV-infected patients in France, relative to the general population. AIDS 2010; 24:1221-1230.

18. Boccara F, Mary-Krause M, Teiger E, Lang S, Lim P, Wahbi K, et al. Acute coronary syndrome in human immunodeficiency virus-infected patients: characteristics and 1 year prognosis. Eur Heart / 2011; 32:41-50.

19. Klein DB, Leyden WA, Xu L, Chao CR, Horberg MA, Towner W], et al. Declining relative risk for myocardial infarction among HIV-positive compared with HIV-negative individuals with access to care. Clin Infect Dis 2015; 60:1278-1280.

20. Rasmussen LD, May MT, Kronborg G, Larsen CS, Pedersen C, Gerstoft J, Obel N. Time trends for risk of severe age-related diseases in individuals with and without HIV infection in Denmark: a nationwide population-based cohort study. Lancet HIV 2015; 2:e288-e298doi: 10.1016/S2352-3018 (15)00077-6.

21. Pocock S, Bueno H, Licour M, Medina J, Zhang L, Annemans L, et al. Predictors of one-year mortality at hospital discharge after acute coronary syndromes: a new risk score from the EPICOR (long-term follow up of antithrombotic management patterns in acute coronary syndrome patients) study. Eur Hear I Acute Cardiovasc Care 2015; 4:509-517.

22. D'Ascenzo F, Cerrato E, Biondi-Zoccai G, Moretti C, Omedè $P$, Sciuto $F$, et al. Acute coronary syndromes in human immunodeficiency virus patients: a meta-analysis investigating adverse event rates and the role of antiretroviral therapy. Eur Heart J 2012; 33:875-880.

23. Carballo D, Delhumeau C, Carballo S, Bähler C, Radovanovic D, Hirschel B, et al. Increased mortality after a first myocardial infarction in human immunodeficiency virus-infected patients; a nested cohort study. AIDS Res Ther 2015; 12:1-9.

24. Tunstall-Pedoe H, Kuulasmaa K, Amouyel P, Arveiler D, Rajakangas AM, Pajak A. Myocardial infarction and coronary deaths in the World Health Organization MONICA Project. Registration procedures, event rates, and case-fatality rates in 38 populations from 21 countries in four continents. Circulation 1994; 90:583-612.

25. Kowalska JD, Friis-Møller N, Kirk O, Bannister W, Mocroft A Sabin C, et al. The Coding Causes of Death in HIV (CoDe) Project: initial results and evaluation of methodology. Epidemiology 2011; 22:516-523.

26. Expert Panel on Detection, Evaluation, and Treatment of High Blood Cholesterol in Adults. Executive summary of the third report of the National Cholesterol Education Program (NCEP) Expert Panel on De- tection, Evaluation, and Treatment of High Blood Cholesterol in Adults (Adult Treatment Panel III). JAMA 2001; 285:2486-2497. 
27. Yeh RW, Sidney S, Chandra M, Sorel M, Selby JV, Go AS. Population trends in the incidence and outcomes of acute myocardial infarction. N Engl J Med 2010; 362:2155-2165.

28. Hsue PY, Giri K, Erickson S, MacGregor JS, Younes N, Shergill $\mathrm{A}$, et al. Clinical features of acute coronary syndromes in patients with human immunodeficiency virus infection. $\mathrm{CirCu}$ lation 2004; 109:316-319.

29. Gazzaruso C, Bruno R, Garzaniti A, Giordanetti S, Fratino P, Sacchi $P$, et al. Hypertension among HIV patients: prevalence and relationships to insulin resistance and metabolic syndrome. I Hypertens 2003; 21:1377-1382.

30. Baekken M, Os I, Sandvik L, Oektedalen O. Hypertension in an urban HIV-positive population compared with the general population: influence of combination antiretroviral therapy. J Hypertens 2008; 26:2126-2133.

31. Calvo-Sánchez $M$, Perelló R, Pérez I, Mateo $M$, Junyent $M$, Laguno $M$, et al. Differences between HIV-infected and uninfected adults in the contributions of smoking, diabetes and hypertension to acute coronary syndrome: two parallel casecontrol studies. HIV Med 2013; 14:40-48.

32. Smith Cl, Ryom L, Weber R, Morlat P, Pradier C, Reiss P, et al. Trends in underlying causes of death in people with HIV from 1999 to 2011 (D:A:D): a multicohort collaboration. Lancet 2014; 384:241-248.

33. Antiretroviral therapy Cohort Collaboration. Causes of death in HIV-1-infected patients treated with antiretroviral therapy, 1996-2006: Collaborative Analysis of 13 HIV Cohort Studies. Clin Infect Dis 2010; 50:1387-1396.

34. Lewden C, May T, Rosenthal E, Burty C, Bonnet F, Costagliola $\mathrm{D}$, et al. Changes in causes of death among adults infected by HIV between 2000 and 2005: the "Mortalité 2000 and 2005" Surveys (ANRS EN19 and Mortavic). I Acquir Immune Defic Syndr 2008; 48:590-598.
35. Ambrose JA, Gould RB, Kurian DC, DeVoe MC, Pearlstein NB, Coppola JT, et al. Frequency of and outcome of acute coronary syndromes in patients with human immunodeficiency virus infection. Am / Cardiol 2003; 92:301303.

36. Matetzky S, Domingo M, Kar S, Noc M, Shah PK, Kaul S, et al. Acute myocardial infarction in human immunodeficiency virus-infected patients. Arch Intern Med 2003; 163:457460.

37. Varriale P, Saravi G, Hernandez E, Carbon F. Acute myocardial infarction in patients infected with human immunodeficiency virus. Am Heart J 2004; 147:55-59.

38. Chaudhry SI, Khan RF, Chen J, Dharmarajan K, Dodson JA, Masoudi FA et al. National trends in recurrent ami hospitalizations 1 year after acute myocardial infarction in medicare beneficiaries: 1999-2010. J Am Heart Assoc 2014; 3:e001197.

39. Rosengren A, Wallentin L, Gitt AK, Behar S, Battler A, Hasdai D. Sex, age, and clinical presentation of acute coronary syndromes. Eur Heart J 2004; 25:663-670.

40. Lorgis L, Cottenet J, Molins G, Benzenine E, Zeller M, Aube H, et al. Outcomes after acute myocardial infarction in HIVinfected patients: analysis of data from a french nationwide hospital medical information database. Circulation 2013; 127:1767-1774.

41. Grunfeld C. Dyslipidemia and its treatment in HIV infection. Top HIV Med 2010; 18:112-118.

42. Canto JG, Kiefe Cl, Rogers WJ, Peterson ED, Frederick PD, French WJ, et al., For the NRMI Investigators. Number of coronary heart disease risk factors and mortality in patients with first myocardial infarction. JAMA 2011; 306:2120 2127. 